The moment of intervention during lactation significantly modified the conception rate : $37 \mathrm{p}$. Ioo of pregnant sows when the treatment started at $\mathrm{MB}_{18}$ versus $45,8 \mathrm{p}$. roo when the injection was made 14 days later.

The induced gestation rate and the prolificacy tended to decrease if the size of the suckled litter increased from 5 to ro and more. The lactation length seemed to interfer with the treatment proposed : for group $\mathrm{MB}_{32}$, fertility was lower in the sows having fed their litter for more than 55 days. The irregularity in returns to oestrus after weaning constituted a handicap : $73.6 \mathrm{p}$. Ioo of the non pregnant sows showed their first oestrus Io days after ceasing of lactation.

\title{
INFLUENCE DE L'ALIMENTATION PENDANT LA CROISSANCE DE LA TRUIE SUR LA MATURITÉ SEXUELLE ET LES PERFORMANCES DE REPRODUCTION : RÉSULTATS PRÉLIMINAIRES
}

\author{
P.-H. DUÉE et M. ÉTIENNE \\ Station de Recherches sur l'Élevage des Porcs, \\ Centre national de Recherches zootechniques, I. N.R. A., \\ 78350 Jouy en Josas

\section{RÉSUMÉ}

Deux expériences ont été réalisées afin de déterminer les effets d'une restriction alimentaire d'une part, d'une carence en protéines et en lysine d'autre part pendant toute ou partie de la croissance, sur l'apparition de la puberté, le taux d'ovulation au premier cestrus et les performances de reproduction à 30 jours de gestation, les animaux ayant été saillis au premier oestrus.

La première expérience porte sur deux lots de I 2 Truies Large White soumises, à partir d'un poids vif de $55 \mathrm{~kg}$ et jusqu'à la puberté, soit à un niveau alimsntaire libéral (consommation maximale $3.28 \mathrm{~kg}$ par jour), soit à une restriction d'environ $45 \mathrm{p}$. Ioo du niveau précédent.

Une sous-alimentation pendant la croissance retarde de deux mois l'âge à la puberté des truies ( 363 contre 296 jours) et abaisse leurs poids à ce stade. De plus, les truies restreintes subissent une diminution du taux d'ovulation ( 12,0 contre ${ }_{13}, 8$ ) qui se répercute sur le nombre d'embryons viables à 30 jours de gestation $(9,0$ contre 12,5$)$. La mortalité embryonnaire apparaît plus élevée dans ce lot de truies restreintes avant la puberté (26,o contre $8,8 \mathrm{p}$. Ioo).

La seconde expérience compare trois lots de 9 truies, à partir de $25 \mathrm{~kg}$ de poids vif et jusqu'à la puberté, recevant suivant une échelle de rationnement, soit un régime à faible taux azoté ( I I, 5 p. I00) supplémenté ou non en lysine (teneur totale des régimes: lot $\mathrm{I}: 0,42 \mathrm{p}$. 100; lot 2 : $0,62 \mathrm{p}$. IоO) soit un régime bien pourvu en protéines (lot $3:$ matières azotées : 17,5 p. Ioo, lysine: o,86 p. I00).

Une restriction azotée retarde la croissance des truies (lot I), principalement pendant les trois premiers mois. Un supplément de L-lysine (lot 2) améliore cependant le gain moyen quotidien. L'apport complémentaire de protéines n'est bénéfique, sur le plan de la croissance, que pendant la première période (trois premiers mois). En ce qui concerne l'âge à la puberté, aucune différence significative n'est observée entre les lots (lot $I: 253$ jours, lot $2: 254$ jours, lot $3: 249$ jours). Par rapport aux autres lots, le poids à la puberté des truies du lot I est significativement plus faible; de même que le taux d'ovulation (lot $1 ; 9,8 ; \operatorname{lot} 2: 12,7 ; \operatorname{lot} 3: \mathbf{1} 3,0$ ). Cette diminution du taux d'ovulation se répercute sur la taille de la portée à 3 o jours (lot $1: 8,2 ; \operatorname{lot} 2: 9,7 ;$ lots $3: 10,0)$. 


\title{
SUMMARY
}

\section{EFFECT OF FEEDING OF GROWING SOWS ON SEXUAL, MATURI'TY AND REPRODUCTIVE PERFORMANCES : PRELIMINARY RESULITS}

Two experiments were carried out in order to determine the effects of feed restriction as well as protein and lysine deficiences during the whole or part of the growth period upon the onset of puberty, ovulation rate at the first oestrus and reproductive performances at 30 days of gestation (animals mated at the first oestrus).

The first experiment was made on 2 groups of 12 Large White sows subjected, from a live weight of $55 \mathrm{~kg}$ and till puberty, either to a liberal feeding level (maximum intake $: 3.28 \mathrm{~kg} /$ day) or to a restriction of about $45 \mathrm{p}$. roo of the previous level. Underfeeding during growth delayed by 2 months the age of the sows at puberty ( 363 versus 296 days) and reduced their weight at this stage. In addition, the ovulation rate of the restricted sows decreased ( 12.0 versus 13.8 ) with repercussions on the number of viable embryos at 30 days of gestation (9.o versus 12.5 ). The mortality of embryos appeared to be higher in this group of sows restricted before puberty $(26.0$ versus 8.8 p. I00).

During the second experiment, three groups of 9 sows were compared from $25 \mathrm{~kg}$ live weight and till puberty. The animals received, according to a restriction schedule, either a diet at a low crude protein level (II.5 p. IOo) supplemented or not with lysine (total content of the diets : group I : 0.42 p. I0o; group $2: 0.62 \mathrm{p}$. I0o) or a diet with a high protein content (crude protein I 7.5 p. Ioo, lysine : 0.86 p. IOJ).

Crude protein restriction delayed the growth of the sows (group I), mainly during the first three months. L-lysine supplementation (group 2) improved the daily mean gain. The complementary supply of protein had only a favourable effect on growth during the first period (first three months). Concerning the age at puberty, no significant difference was noticed between the groups (group I : 253 days; group $2: 254$ days; group $3: 249$ days). As compared to the other groups, the weight at puberty of the sows from group I was significantly lower and this was also the case for the ovulation rate (group $1: 9.8 ;$ group $2: 12.7 ;$ group $3: 13$.$) . This decrease in the ovulation$ rate had a consequential effect on the litter size at 3 o days (group $1: 8.2 ;$ goup $2: 9.7 ;$ group 3 : ro.o).

\section{ÉTUDE DU BESOIN EN LYSINE DE LA TRULE GESTANTE NULLIPARE}

\author{
P. H. DUÉE et A. RÉRAT* \\ Station de Recherches sur l'Elevage des Porcs, \\ * Laboratoire de Physiologie de la Nutrition, \\ Centre national de Recherches zootechniques, I. N. R. A., \\ 78350 Jouy en Josas
}

\section{RÉSUMÉ}

Une étude a été entreprise dans le but de déterminer le besoin en lysine de la truie gestante nullipare. A cet effet, 4 lots de 6 à 7 truies Large White dont un lot témoin de truies vides ont été comparés pendant un cycle de reproduction sur la base des variations des poids des animanx, des 